\title{
An in situ approach to characterizing photosynthetic gas exchange of rice panicle
}

\section{Tiangen Chang}

Institute of Plant Physiology and Ecology Shanghai Institutes for Biological Sciences

https://orcid.org/0000-0003-1485-1992

\section{Qing-Feng Song}

Institute of Plant Physiology and Ecology Shanghai Institutes for Biological Sciences

\section{Honglong Zhao}

Institute of Plant Physiology and Ecology Shanghai Institutes for Biological Sciences

\section{Shuoqi Chang}

HHRRC

\section{Changpeng Xin}

Partner Institute for Computational Biology Chinese Academy of Sciences and Max Planck Society

\section{Mingnan Qu}

Institute of Plant Physiology and Ecology Shanghai Institutes for Biological Sciences

\section{Xinguang Zhu ( $\nabla$ zhuxg@cemps.ac.cn )}

https://orcid.org/0000-0001-9178-7336

\section{Methodology}

Keywords: rice panicle, reproductive organs, in situ, photosynthetic characteristics phenotyping, grain setting rate, P-chamber

Posted Date: May 28th, 2020

DOI: https://doi.org/10.21203/rs.2.20971/v2

License: (c) (i) This work is licensed under a Creative Commons Attribution 4.0 International License.

Read Full License

Version of Record: A version of this preprint was published at Plant Methods on July 6th, 2020. See the published version at https://doi.org/10.1186/s13007-020-00633-1. 


\section{Abstract}

Background: Photosynthesis of reproductive organs in $\mathrm{C}_{3}$ cereals is generally regarded as important to crop yield. Whereas, photosynthetic characteristics of reproductive organs are much less understood as compared to leaf photosynthesis, mainly due to methodological limitations. To date, many indirect methods have been developed to study photosynthesis of reproductive organs and its contribution to grain yield, such as organ shading, application of herbicides and photosynthetic measurement of excised organs or tissues, which might be intrusive and cause biases. Thus, a robust and in situ approach needs to be developed.

Results: Here we report the development of a custom-built panicle photosynthesis chamber (P-chamber), which can be connected to standard infrared gas analyzers to study photosynthetic/respiratory rate of a rice panicle. With the P-chamber, we measured panicle photosynthetic characteristics of seven highyielding elite japonica, japonica-indica hybrid and indica rice cultivars. Results show that, 1) rice panicle is photosynthetically active during grain filling, and there are substantial inter-cultivar variations in panicle photosynthetic and respiratory rates, no matter on a whole panicle basis, on an area basis or on a single spikelet basis; 2 ) among the seven testing cultivars, whole-panicle gross photosynthetic rates are $17-54 \mathrm{nmol} \mathrm{s}^{-1} 5$ days after heading under photon flux density (PFD) of $2000 \mu \mathrm{mol}$ (photons) $\mathrm{m}^{-2} \mathrm{~s}^{-1}$, which represent some $20-38 \%$ of that of the corresponding flag leaves; 3 ) rice panicle photosynthesis has higher apparent $\mathrm{CO}_{2}$ compensation point, light compensation point and apparent $\mathrm{CO}_{2}$ saturation point, as compared to that of a typical leaf; 4 ) there is a strong and significant positive correlation between gross photosynthetic rate 5 days after heading on a single spikelet basis and grain setting rate at harvest (Pearson correlation coefficient $r=0.93, p$-value $<0.0001$ ).

Conclusions: Rice panicle gross photosynthesis is significant, has great natural variation, and plays an underappreciated role in grain yield formation. The P-Chamber can be used as a tool to study in situ photosynthetic characteristics of irregular non-foliar plant organs, such as ears, culms, leaf sheaths, fruits and branches, which is a relatively less explored area in current cereal breeding community.

\section{Background}

In cereal crops such as rice and wheat, there are two major sources of assimilates used for grain filling, i.e., the post-anthesis photosynthesis and the pre-anthesis assimilates stored in the stem. Under nonstress conditions, the post-anthesis photosynthesis contributes greater to grain yield than the preanthesis stored assimilates [1-4]. Leaves, especially flag leaves located at the upmost of stems, have been believed to be the dominant contributor of post-anthesis photosynthesis [5, 6]. Nevertheless, reproductive organs, including glumes, caryopsis pericarps, and awns, are green before mature and photosynthetically active $[7,8]$, suggesting a possibility of them being a major source of photosynthate for grain filling as well. In fact, reproductive organs have several potential advantages over leaves in terms of photosynthate production and transportation: 1) they generally locate at the upper canopy, where light levels are higher than those at the lower canopy; 2) they are physically closer to the 
developing grains than the leaves, which shorten the path of assimilates transport to developing grains $[9]$; 3) they have large surface area, e.g. the ear surface areas were 1.1-5.5 folds greater than that of the corresponding flag leaves in wheat and barley [6]; 4) reproductive organs tend to senesce later than leaves, especially under adverse conditions such as drought $[10,11]$. Due to these reasons, photosynthesis of reproductive organs gained more and more attraction in recent years (see reviews in [12-15]).

In wheat and barley, ear photosynthesis is a major source of photosynthate for grain filling; a large photosynthetic area and high photosynthetic activity from both the green glumes and awns are major factors underlying higher ear photosynthesis $[6,16,17]$. Using ear-shading and/or stem-shading methods, ear photosynthesis was estimated to contribute $10 \%$ to $65 \%$ of the grain yield in different wheat lines and under different growth conditions [16-20]. By analyzing the carbon isotope composition in different organs, it was estimated that ear photosynthesis contributed $47 \%$ to $100 \%$ of the grain yield in six highyielding bread wheat lines under well-managed conditions [21, 22]. In a retrospective study, by using 15 winter wheat cultivars released from 1980 to 2012 in North China Plain, it was reported that the contribution of ear photosynthesis to grain yield doubled (from around $30 \%$ to around $60 \%$ ) during breeding [18]. Although the exact proportion of ear photosynthesis to total grain yield varies, breeding cultivars with higher ear photosynthesis was recognized as a new mechanism to improve wheat yield potential $[14,15,23]$.

In contrast to the significant importance of ear photosynthesis in wheat and barley, rice panicle has been traditionally regarded as a sink organ with negligible photosynthetic contribution to grain yield [24]. For example, Tsuno et al. (1975) estimated that net panicle photosynthesis is about $5 \%$ of that of an active photosynthesizing rice leaf [25]; Takeda and Maruta (1956) estimated that panicle photosynthesis contributes $8 \%$ of the rice grain yield [26]. Reflecting the notion of rice ear photosynthesis being of little importance to grain filling, some researchers recommended lowering spike position in a canopy as much as possible to increase canopy photosynthesis by minimizing shading leaves by panicles [27].

Is panicle photosynthesis in rice really of little importance for grain filling? More and more evidences are suggesting the opposite. For example, Imaizumi et al. (1990) found that whole-panicle gross amount of photosynthetically assimilated $\mathrm{CO}_{2}$ was $30 \%$ of that in a flag leaf, and spikelets had a similar photosynthetic capability to a flag leaf on the basis of $\mathrm{Chl}$ [8]. It has been shown that rice panicle contains higher amount of chloroplast $\mathrm{NAD}(\mathrm{P}) \mathrm{H}$ dehydrogenase-like complex, and maintains a similar or even higher quantum yield of PSII than that of the flag leaf from heading to harvest [28]. There are also evidences showing a potential important role of rice panicle photosynthesis in maintaining grain filling under moderate stress conditions. For example, under moderate wetting and drying irrigation after anthesis, genes that function in photosynthesis and carbohydrate metabolism were upregulated in inferior spikelets, together with a simultaneous increase of grain filling rate and grain weight of the inferior spikelets [29]. 
One major factor attributing to the inconsistency regarding the importance of photosynthesis of reproductive organs in grain filling is to the lack of robust methods to measure photosynthesis in organs with a complex three-dimensional geometry $[12,22,23]$. Many indirect methods have been developed to study photosynthesis of reproductive organs [23], e.g. through ear (awn) removal/shading or application of herbicides [17, 27, 30], isotope tracing [21], gas exchange measurement of excised spikelets [6, 8] and chlorophyll fluorescence measurement for plants cultured in pots [28]. Among these methods, the shading treatments or applications of herbicides may affect other function of treated organs and/or trigger compensation effects of unaffected organs [20,22,31-35]. The stable isotope discrimination method calculated contributions of different organs to grain yield based on instant carbon isotope in water-soluble fraction in different tissues at mid-grain filling stage and carbon isotope in mature grains $[12,21,22]$. The accuracy of this isotope discrimination method might be affected by the dynamic environment (e.g. temperature and air humidity) and physiological processes other than photosynthesis (e.g. assimilates transport and ear night respiration) during the whole grain filling season [12, 21, 22]. Gas exchange measurement on excised ears or spikelets is an intrusive method and it can cause bias due to an alteration of ear natural architecture and posture [27].

Thus, the main objectives of this study are: 1) to develop a direct and non-intrusive method for gas exchange measurement of rice panicles; 2) to explore panicle photosynthetic characteristics and the intercultivar variations of photosynthetic gas exchange parameters; 3 ) and to study the relationship between panicle photosynthetic gas exchange parameters and grain yield related agronomic traits.

\section{Results}

\section{Performance of the panicle photosynthesis P-chamber}

The P-chamber is connected to a gas analyzer Li-6400 (Li-Cor Inc., Lincoln, Nebraska, USA) to measure gas exchange rate of a rice panicle (Fig. 1a, b). The panicle is illuminated with LED light source (Fig. 1c, d). The LED light source emits pure white light (light wavelength information is shown in Fig. 1f). The photon flux density (PFD) is in a range of $\pm 10 \%$ of set value on $87 \%$ of the total $30 \times 5 \mathrm{~cm}$ light field (Fig. 1e). At a room temperature of $25^{\circ} \mathrm{C}$ with a flow rate of $700 \mu \mathrm{mol} \mathrm{s}{ }^{-1}$, temperature rise in the chamber at PFD of $2000 \mu \mathrm{mol}$ (photons) $\mathrm{m}^{-2} \mathrm{~s}^{-1}$ is $4.3 \pm 0.7^{\circ} \mathrm{C}$.

To test the leakage of the P-chamber, we recorded $\Delta\left[\mathrm{CO}_{2}\right]$ (the difference between $\mathrm{CO}_{2}$ concentration in the $\mathrm{P}$-chamber and the set reference $\mathrm{CO}_{2}$ concentration in the reference pipe) at different time after closure of the P-chamber. With an initial $\Delta\left[\mathrm{CO}_{2}\right]$ value of around $500 \mu \mathrm{mol} \mathrm{mol}{ }^{-1}$, the $\Delta\left[\mathrm{CO}_{2}\right]$ values were stabilized within 8 min under different flow rates and different $\mathrm{CO}_{2}$ concentrations (Fig. 1g). The final $\Delta\left[\mathrm{CO}_{2}\right]$ values were $\leq 1.6 \mu \mathrm{mol} \mathrm{mol}{ }^{-1}$ and $\leq 1.3 \mu \mathrm{mol} \mathrm{mol}^{-1}$ at a flow rate of 500 and $700 \mu \mathrm{mol} \mathrm{s}{ }^{-1}$, respectively (Fig. 1g). During a typical measurement of panicle photosynthetic rate and respiratory rate, the light source was turned on before the rice panicle was enclosed, and the photosynthetic rate was recorded after photosynthetic rate reading was stabilized; then the light source was turned off, and the 
respiratory rate was recorded after respiratory rate reading was stabilized (Fig. 1h). A comprehensive measurement for photosynthetic and respiratory rates of a rice panicle usually took $10 \sim 20$ min after the panicle was enclosed in the P-chamber, depended on size and photosynthetic activity of the panicle.

\section{Quantification of rice panicle photosynthesis}

We first used the P-chamber to measure the in situ whole-panicle photosynthetic gas exchange parameters 5 days after heading for different rice cultivars when the panicles were still erect or semierect. Specifically, whole-panicle net photosynthetic rate (panicle $A_{\text {net }}$ ) and dark respiratory rate (panicle $R_{\mathrm{d}}$ ) were measured; and whole-panicle gross photosynthetic rate (panicle $A_{\text {gross }}$ ) was calculated as a sum of panicle $A_{\text {net }}$ and panicle $R_{\mathrm{d}}$. In addition, average spikelet $A_{\text {gross' }} A_{\text {net }}$ and $R_{\mathrm{d}}$ were calculated by dividing panicle $A_{\text {gross }} A_{\text {net }}$ and $R_{\mathrm{d}}$ by the spikelet number of a panicle.

Notably, substantial inter-cultivar variations in photosynthetic gas exchange parameters among rice cultivars were found, for both values of a whole panicle and values normalized by spikelet number. For example, the spikelet $A_{\text {net }}$ and panicle $A_{\text {net }}$ were $0.012 \sim 0.051 \mathrm{nmol} \mathrm{s}^{-1}$ and $2.7 \sim 12.0 \mathrm{nmol} \mathrm{s}^{-1}$ in 2015 , and were $-0.014 \sim 0.075 \mathrm{nmol} \mathrm{s}^{-1}$ and $-3.3 \sim 15.0 \mathrm{nmol} \mathrm{s}^{-1}$ in 2016, respectively (Table 1). Panicle $A_{\text {gross }}$ varied from 17.1 to $53.6 \mathrm{nmol} \mathrm{s}^{-1}$ under PFD of $2000 \mu \mathrm{mol}$ (photons) $\mathrm{m}^{-2} \mathrm{~s}^{-1}$ for the seven rice cultivars (Table 1). Moreover, indica type rice cultivars (YLY900, CY1000, SY63 and 9311) had an overall significantly higher $A_{\text {gross }}, A_{\text {net }}$ and $R_{\mathrm{d}}$ than japonica and japonica-indica hybrid type rice cultivars (XS134, YY538 and YY17), both on whole panicle basis and on single spikelet basis (Fig. 2).

In 2016, we further measured area of panicles and area of the corresponding flag leaves, and then quantified $A_{\text {gross, }} A_{\text {net }}$ and $R_{\mathrm{d}}$ on an area basis by dividing panicle $A_{\text {gross' }}, A_{\text {net }}$ and $R_{\mathrm{d}}$ by the area of a panicle (Fig. S1; see detailed procedure used to calculate panicle surface area in Materials and Methods). As a result, we found spikelets contributed the majority of the panicle area, whereas branches only accounted for $24 \sim 33 \%$ of the panicle area; moreover, total area of a panicle (single side) was $72 \sim 121$ $\mathrm{cm}^{2}$, which was $20 \sim 124 \%$ higher than that of a flag leaf (Table 2). On an area basis, $A_{\text {net }}$ of panicles were very low, i.e., only $-0.6 \sim 2.2 \mu \mathrm{mol} \mathrm{m} \mathrm{m}^{-2} \mathrm{~s}^{-1}$, under a PFD of $2000 \mu \mathrm{mol}$ (photons) $\mathrm{m}^{-2} \mathrm{~s}^{-1}$; whereas $A_{\text {gross }}$ were $2.1 \sim 7.2 \mu \mathrm{mol} \mathrm{m}{ }^{-2} \mathrm{~s}^{-1}$, much higher than $A_{\text {net, }}$ as a result of high $R_{\mathrm{d}}$, i.e., $2.1 \sim 6.1 \mu \mathrm{mol} \mathrm{m}^{-2} \mathrm{~s}^{-1}$ (Table 3).

Given these different representations of gas exchange rates, i.e., on a panicle basis, on a spikelet basis and on an area basis, what's the relations between them? Positive correlations between values on different bases were found for all the three parameters $A_{\text {gross }}, A_{\text {net }}$ and $R_{\mathrm{d}}$ (the Pearson correlation coefficient r $=0.59 \sim 0.99$; Fig. 3a-i). Interestingly, we found that $A_{\text {net }}$ per panicle was strongly positively correlated with $A_{\text {net }}$ per unit panicle area (the Pearson correlation coefficient r=0.97; Fig. 3e), in contrast to that for $A_{\text {gross }}$ and $R_{\mathrm{d}}$ (the Pearson correlation coefficient r $=0.77$ and 0.59 , respectively; Fig. $3 \mathrm{~b}, \mathrm{~h}$ ). In addition, spikelet based $A_{\text {gross }}, A_{\text {net }}$ and $R_{\mathrm{d}}$ were closely related to area based $A_{\text {gross, }}, A_{\text {net }}$ and $R_{\mathrm{d}}$ (the 
Pearson correlation coefficient $r=0.97-0.99$; Fig. 3c, $f, i)$, as a result of a tight relationship between panicle area and spikelet number (the Pearson correlation coefficient r=0.95; Fig. 4).

\section{Characterization of rice panicle photosynthesis}

To further characterize rice panicle photosynthesis, we measured dynamic changes of panicle $A_{\text {gross }}$ and $R_{\mathrm{d}}$ for seven rice cultivars during grain filling in 2016 (Fig. 5). Firstly, panicle $A_{\text {gross }}$ and $R_{\mathrm{d}}$ were highest at early grain filling stage, then slowly decreased over time. Notably, both $A_{\text {gross }}$ and $R_{\mathrm{d}}$ could still be detected even 40 days after heading, i.e., panicle photosynthesis and respiration were active throughout the grain-filling season. It is worth mentioning here that the panicle $A_{\text {gross }}$ should be interpreted as the maximal photosynthetic potential, as the panicle was held upright during measurement, which was not the natural state after early grain filling stage for some cultivars.

We further measured the photosynthetic light and $\mathrm{CO}_{2}$ response patterns of a panicle using rice cultivar YY17. Although the shapes of both response curves are similar to that of a leaf, there are several differences. Firstly, the apparent $\mathrm{CO}_{2}$ and light compensation points of a panicle were about $180 \mu \mathrm{mol}$ $\mathrm{mol}^{-1}$ and $390 \mu \mathrm{mol} \mathrm{m} \mathrm{s}^{-1}$ (Fig. 6), much higher than those of a leaf, which are usually $<100 \mu \mathrm{mol} \mathrm{mol}{ }^{-1}$ and $<50 \mu \mathrm{mol} \mathrm{m} \mathrm{m}^{-2} \mathrm{~s}^{-1}$, respectively. Secondly, the panicle photosynthetic rate was still not saturated at very high air $\mathrm{CO}_{2}$ concentration $\left(1800 \mu \mathrm{mol} \mathrm{mol}{ }^{-1}\right.$; Fig. 6a), which also differed from that of a typical leaf.

\section{Correlation between panicle photosynthetic gas exchange parameters and grain yield related agronomic traits}

Finally, we studied the relationship between panicle photosynthetic gas-exchange parameters measured 5 days after heading (Table 1) and six grain yield related agronomic traits collected at harvest across two years, i.e., spikelet number per panicle, panicle length, spikelet density (defined as spikelet number per centimeter of panicle length), 1000-grain weight, grain setting rate and panicle weight (Table 4). Firstly, there were positive correlations between different panicle photosynthetic gas-exchange parameters (Fig. 7). For example, significant positive correlations were found between $A_{\text {gross }}$ and $A_{\text {net }}$ of a whole panicle (Pearson correlation coefficient $\mathrm{r}=0.87, p$-value $<0.001)$, between $A_{\text {gross }}$ and $R_{\mathrm{d}}$ of a whole panicle $(\mathrm{r}=$ 0.94, $p$-value $<0.0001)$, between $A_{\text {gross }}$ and $A_{\text {net }}$ per spikelet $(r=0.93$, $p$-value $<0.0001)$, and between $A_{\text {gross }}$ and $R_{\mathrm{d}}$ per spikelet $(r=0.97, p$-value $<0.0001)$. In contrast, both positive and negative correlations were found between grain yield related agronomic traits, e.g. significant negative correlations were found between 1000-grain weight and spikelet number per panicle, but significant positive correlations were found between 1000-grain weight and grain setting rate (Fig. 7). Notably, strong positive correlations were

found between $A_{\text {gross }}, A_{\text {net }}, R_{\mathrm{d}}$ per spikelet and grain setting rate, 1000-grain weight. In particular, the Pearson correlation coefficient $r$ is 0.93 ( $p$-value $<0.0001)$ between $A_{\text {gross }}$ per spikelet and grain setting rate (Fig. 7). Concurrently, we found that $A_{\text {gross }} A_{\text {net }}$ and $R_{\mathrm{d}}$ of a whole panicle had a moderate positive correlation with panicle dry weight at harvest $(r=0.39 \sim 0.55)$; whereas $A_{\text {gross }} A_{\text {net }}$ and $R_{\mathrm{d}}$ per spikelet were not correlated with panicle dry weight at harvest $(r=-0.18 \sim 0.12)$. In addition, all the six panicle 
photosynthetic gas exchange parameters were found to be positively correlated with panicle length ( $r=$ $0.6 \sim 0.85)$, whereas they were negatively correlated with spikelet density $(r=-0.82 \sim-0.28)$. Finally, no correlations were found between $A_{\text {gross }}, A_{\text {net }}, R_{\mathrm{d}}$ of a whole panicle and spikelet number per panicle $(\mathrm{r}=$ $-0.2 \sim 0.1)$.

\section{Discussion}

Reproductive organs of cereal crops have been shown photosynthetically active, and photosynthesis in ear of wheat and barley has attracted great research interest $[12,13][14,15]$. Current high-yield rice cultivars usually have much bigger ears with many spikelets compared with wheat or barley. For example, the newly bred rice cultivar YLY900, which have reached record-high yield of 15 tons ha-1 [36], and another even higher yielded rice cultivar CY1000, have an extra-large panicle size of exceeding 350 and 400 spikelets per panicle, respectively (Table 4). As a result, the green area of a rice panicle can even be larger than a flag leaf (Table 2). Furthermore, considering that the panicles locate at the upper part of a canopy, they can intercept a considerably amount of solar radiation. All these suggest a great role of panicle photosynthesis in rice grain filling. However, compared to leaf photosynthesis, panicle photosynthesis is much less studied, largely due to the methodological limitations $[12,22,23]$. Therefore, new tools and methods are needed to enable better characterization of rice panicle photosynthesis and provide an accurate evaluation of the impact of panicle photosynthesis on rice grain yield.

Here we reported the development of a new panicle photosynthesis P-chamber, which can be connected to a standard infrared gas analyzer to enable direct measurement of gas exchange parameters.

Compared to previously reported cuvettes for rice or wheat ear gas exchange measurement $[8,17,22,37]$, the P-chamber has several new features. First, it is made air-tight with very limited leakage under different $\mathrm{CO}_{2}$ concentrations and flow rates, which enables accurate and fast measurement of gas exchange rate. Secondly, it has a large cuvette volume for gas exchange measurement of a whole rice panicle in situ. The large cuvette volume enables measurement of panicles of irregular shape. We expect that it can also be used to measure inflorescence of Arabidopsis, wheat, rape and soybean and other plant organs such as stem, fruit, and branch in situ. Moreover, the chamber is opaque and the PFD inside is uniformly distributed and can be precisely controlled, which enables studying response of photosynthesis to PFD.

Using the P-chamber, we studied quantitative characteristics of rice panicle photosynthesis. First of all, to facilitate comparison between tissues, gas exchange rates are normalized. There are three commonly adopted approaches to normalize gas exchange rates of foliar and non-foliar organs, i.e., 1) normalization based on organ number, which is widely used for cereal ears $[25,38]$; 2) normalization based on area, which is commonly used for leaves [37, 39]; and 3) normalization based on chlorophyll content, which is applicable for both foliar and non-foliar organs $[8,40]$. For ears of cereal crops, it is labor-saving and technically easier to measure gas exchange rate on a whole ear basis or on a spikelet basis rather than on an area basis or chlorophyll basis. However, what's the relationship between gas exchange rates normalized on different bases? Here we show that gas exchange rate on a spikelet basis is highly correlated to gas exchange rate on an area basis (Pearson correlation coefficient $r=0.97-0.99$; 
Fig. 3). This result indicates that we may use spikelet-based spike photosynthesis rate as a surrogate for the area-based spike photosynthesis rate, as the former one is non-intrusive and technically easier. For the seven rice cultivars used in this study, we have the following equation to convert sipkelet number to panicle area (Fig. 4):

Panicle area $=0.266$ * Spikelet number +9.84 Eqn. 1

Strikingly, $A_{\text {net }}$ on a panicle basis is also highly correlated to $A_{\text {net }}$ on an area basis for the seven rice cultivars used in this study (Pearson correlation coefficient r=0.97; Fig. 3). This result indicates that panicle $A_{\text {net }}$ is largely determined by $A_{\text {net }}$ per unit area rather than its spikelet number or green surface area.

Secondly, we found that as a result of high respiratory rate and large panicle area, $A_{\text {gross }}$ of a whole panicle 5 days after heading could be as high as 17 to $54 \mathrm{nmol} \mathrm{s}^{-1}$ under a PFD of $2000 \mu \mathrm{mol}$ (photons) $\mathrm{m}^{-2} \mathrm{~s}^{-1}$. With an assumed typical photosynthetic rate of $25 \mu \mathrm{mol} \mathrm{m} \mathrm{m}^{-2} \mathrm{~s}^{-1}$ under a PFD of $2000 \mu \mathrm{mol}$ (photons) $\mathrm{m}^{-2} \mathrm{~s}^{-1}$ [41-43], the $A_{\text {gross }}$ of whole flag blades for the seven rice cultivars were 82 to $220 \mathrm{nmol} \mathrm{s}^{-}$ 1 . This estimation resulted in the ratio between panicle $A_{\text {gross }}$ and flag leaf $A_{\text {gross }}$ to be $20-38 \%$ (Table 5). This result is comparable to a previous report, where $A_{\text {gross }}$ of a panicle is $30 \%$ of a flag leaf [8]. Concurrently, though panicle photosynthetic activity gradually decreased during grain filling, it still maintained $\mathrm{CO}_{2}$ uptake activity even 40 days after heading, especially for the newly released super high yield hybrid rice cultivars, YLY900 and CY1000 (Fig. 5a). Maintaining photosynthetic activity of a panicle till the end of rice grain filling has been reported earlier as well $[28,40]$. The contribution of panicle photosynthesis to rice grain yield cannot be precisely calculated in the current study due to the lack of the light environments for panicle throughout the grain filling season. However, the contribution of panicle photosynthesis to grain filling can be estimated based on measured rates of respiration. Specifically, if we assume a constant respiratory rate during the daytime, i.e., from 6:00 AM to 18:00 PM, the total daytime-respired $\mathrm{CO}_{2}$ during the whole grain filling season for the seven cultivars is $21-40 \mathrm{mmol}$ (an integration of the Tot. $R_{\mathrm{d}}$ in Fig. 2), which is equivalent to $0.6-1.2 \mathrm{~g} \mathrm{CH}_{2} \mathrm{O}$ and accounts for $12.1-17.0 \%$ of the panicle weight at harvest (Table 4). Namely, by refixation of daytime-respired $\mathrm{CO}_{2}$, panicle photosynthesis can apparently contribute $12-17 \%$ of the final grain yield. Considering that during most of the grain filling season, panicle maintains a positive carbon uptake (Fig. 5), we conclude that the apparent contribution of panicle photosynthesis to grain filling will be higher than $12 \%$. Combination of the photosynthetic light response curve measured by P-chamber with an elaborate three-dimensional modeling of rice panicles and leaves [44], light environments within a canopy can be calculated and the daily and season-long photosynthetic contribution of a panicle can be precisely quantified.

Thirdly, there are substantial inter-cultivar variations in panicle photosynthetic and respiratory rates 5 days after heading, both on a whole panicle basis and on a spikelet basis (Table 1). Indica cultivars have $\sim 402 \%$ and $\sim 693 \%$ higher panicle net photosynthetic rates per panicle and per spikelet than japonica and japonica-indica hybrid cultivars, respectively; meanwhile, indica cultivars have $\sim 68 \%$ and $\sim 83 \%$ higher 
panicle respiratory rates per panicle and per spikelet, respectively (Fig. 2). Overall, indica cultivars show $\sim 94 \%$ and $\sim 122 \%$ increase in panicle gross photosynthetic rates on the panicle basis and on the spikelet basis, respectively (Fig. 2). One of the factors contributing to these differences might be panicle morphology. For example, the high-yielding japonica rice cultivars usually have erect and densely-packed panicles [45], while the indica rice cultivars typically have drooping and loosely-packed panicles [46]. Indeed, highly negative correlations between spikelet density and respiratory rate per spikelet (Pearson correlation coefficient $r=-0.82$; Fig. 7), and between spikelet density and net photosynthetic rate per spikelet were found in this study (Pearson correlation coefficient $r=-0.66$; Fig. 7). The mechanisms by how spikelet density could influence both panicle photosynthesis and respiration are not clear. Intersubspecies differences in photosynthetic apparatus and metabolism may also exist, which need to be further studied. Similar to this, there is a significant difference between leaf photosynthetic rates between indica and japanica cultivars, the molecular mechanism of which also awaits clarification $[47,48]$.

Fourthly, rice panicles show differences in photosynthetic response pattern to light intensities and $\mathrm{CO}_{2}$ concentrations compared to the leaves. Specifically, rice panicle has high photosynthetic light compensation point, and has high apparent $\mathrm{CO}_{2}$ compensation and saturation points. Consistent with our finding here in rice, wheat ear was also found to have higher $\mathrm{CO}_{2}$ compensation and saturation points than that of a flag leaf, which might be due to its high respiratory rate and different stomatal conductance response pattern [37].

Correlation study between panicle photosynthetic gas exchange parameters and grain yield related agronomic traits further shows a significant role of panicle photosynthesis in rice grain filling.

Specifically, we found spikelet gross photosynthetic rates at early grain filling stage were strongly and significantly correlated with grain setting rate $(r=0.93)$ and 1000-grain weight $(r=0.84$; Fig. 7). These results indicate that activity of the spikelet as a source and as a sink may closely linked. It is likely that the activity of the spikelet as a photosynthetic source promotes the activity of the grain as a sink. The detailed mechanism of this "source-sink" correlation is still not clear. Earlier studies on wheat offer a few possibilities: 1) panicle photosynthesis may supply oxygen to the hypoxic regions deep within the developing seed to increase its metabolic activity [49]; 2) the transpiration accompanying panicle photosynthesis not only supports the transfer of nutrients and signal molecules from xylem to spikelets, but also regulates panicle temperature to avoid over-heating [50,51];3) panicle photosynthesis can generate assimilatory power, i.e., ATP and reduced ferredoxin, which are required to support glume nitrogen assimilation, a major source of nitrogen in wheat grain [52].

Finally, the method of directly measuring reproductive organ gas exchange rate has a range of potential applications. Firstly, it can help accurately simulate photosynthesis from non-foliar organs and evaluate their role in canopy photosynthesis based on three-dimensional canopy photosynthesis modeling [44, 53]. Secondly, as large natural variations of panicle photosynthetic and respiratory rates exist between cultivars, the genetic basis can be explored by measuring panicle gas exchange parameters in rice genetic populations. Thirdly, the diurnal and seasonal panicle respiratory rate change can be measured to 
trace grain filling dynamics to support identification of new options to improve panicle grain filling patterns $[43,54]$.

\section{Conclusions}

Here we report the design and application of a new device, the P-chamber. The features of large cuvette volume, air tight, and programmable light intensity inside the P-chamber enable in situ characterization of photosynthetic gas exchange of a whole plant organ. With the P-chamber, for the first time, we characterized whole-panicle photosynthetic light and $\mathrm{CO}_{2}$ response patterns, quantified variations of panicle photosynthesis between cultivars and identified correlations between panicle photosynthetic gas exchange parameters and agronomic traits in rice. Further application of the P-chamber will facilitate study on photosynthetic characteristics and contribution of irregular photosynthetic organs, especially the non-foliar photosynthetic organs, e.g. inflorescence of cereals and other plant organs such as stem and branch.

\section{Materials And Methods}

\section{Plant materials and experimental design}

Rice plants were grown in a paddy field at Songjiang breeding station of the Institutes of Plant Physiology and Ecology, Chinese Academy of Sciences, Shanghai, China ( $\left.30^{\circ} 56^{\prime} 44^{\prime \prime} \mathrm{N}, 121^{\circ} 8^{\prime} 1^{\prime \prime} \mathrm{E}\right)$ in 2015 and 2016. Seeds were sown on seedbeds after germination on 1 June 2015 and 5 June 2016, and seedlings were transplanted to the field on 26 June 2015 and 29 June 2016. In both years, one plant was transplanted into a hill with a spacing of $20 \mathrm{~cm}$ between hills and $20 \mathrm{~cm}$ between rows. The cultivars were planted in plots. Plots were arranged in blocks with five replicates, each containing $56(7 \times 8)$ plants. Basal fertilizer was applied at a rate of $120 \mathrm{~kg} \mathrm{~N} \mathrm{ha}^{-1}, 65 \mathrm{~kg} \mathrm{P} \mathrm{ha}^{-1}$ and $65 \mathrm{~kg} \mathrm{~K} \mathrm{ha}^{-1}$. Additional $\mathrm{N}$ fertilizer was top-dressed at a rate of $80 \mathrm{~kg} \mathrm{~N} \mathrm{ha}^{-1} 3$ weeks after transplanting. Weeds, pests and diseases were controlled following common agronomic practice in the region. In 2015, five rice cultivars were grown for experiments: two recently bred indica super high yield hybrid cultivars Y-Liang-You 900 (YLY900; http://www.ricedata.cn/variety/varis/614537.htm) and Chao-You 1000 (CY1000; http://www.ricedata.cn/variety/varis/616642.htm), one widely grown traditional indica hybrid cultivar Shan-You 63 (SY63; http://www.ricedata.cn/variety/varis/601174.htm), one indica inbred cultivar YangDao 6 (9311; http://www.ricedata.cn/variety/varis/600611.htm) and one elite japonica inbred cultivar Xiu-Shui 134 (XS134; http://www.ricedata.cn/variety/varis/603176.htm). In 2016, in spite of the above mentioned 5 cultivars, two additional japonica-indica hybrid cultivars, Yong-You 538 (YY538; http://www.ricedata.cn/variety/varis/613563.htm) and Yong-You 17 (YY17; http://www.ricedata.cn/variety/varis/612347.htm), were grown for experiments. The heading date and harvest date of main stems for these rice cultivars in two years were given in Table S1.

\section{Construction of the custom-designed panicle chamber}


To enable direct and non-intrusive measurement of panicle photosynthesis, we built a panicle photosynthesis measurement chamber (P-chamber), which can be used together with infrared gas analyzers to measure photosynthetic and respiratory rates of a whole rice panicle. The chamber body is made of aluminum, with cooling fins and cooling fans on both sides (Fig. 1C). The chamber body has a dimension of $30 \times 5 \times 5 \mathrm{~cm}$. The air inside the chamber was mixed with two air-mixing fans inside the chamber (F2008ES-05WAV, SHICOH IC FAN, Japan), light source and a PFD control system (Fig. 1C, d). The inner space is uniformly illuminated with 192 light-emitting diodes (LEDs; CREE XML T6, Guangdong Benbon Electrical Co., Ltd) on an $30 \times 5 \mathrm{~cm}$ Aluminum substrate (Dongxing electronic technology Co., Ltd) for which the PFD can be precisely controlled to span from 0 to $2000 \mu \mathrm{mol}$ (photons) $\mathrm{m}^{-2} \mathrm{~s}^{-1}$ (Fig. 1d). The PFDs in the P-chamber under different input voltages on LEDs were measured with an irradiance sensor (LightScout Light Sensor Reader, LightScout, Spectrum Technologies, Inc. USA). During measurement, the P-chamber is connected to a standard Infra-red gas analyzer Li-6400, and the rice panicle is held upright and fully enclosed in the chamber (Fig. 1a, b). Flow rate and $\mathrm{CO}_{2}$ concentration of influx air are controlled by LI-6400, and data are recorded and stored in LI-6400. Temperature inside the Pchamber was not controlled during measurement. The ambient air temperature for each measurement was recorded (see in Table S2 and Table S3).

\section{Measurement of panicle photosynthetic gas exchange parameters}

Twenty panicles were randomly selected and labeled at heading for each rice cultivar, which were used to measure photosynthetic gas exchange parameters and yield related agronomic traits. Three and five panicles among these twenty were used to measure whole-panicle net photosynthetic rate and dark respiratory rate in 2015 and 2016, respectively. During each measurement, the $\mathrm{CO}_{2}$ concentration was set to $400 \mu \mathrm{mol} \mathrm{mol}{ }^{-1}$, the air flow rate was set to $700 \mu \mathrm{mol} \mathrm{s}^{-1}$. For net photosynthetic rate measurement, the PFD was set to $2000 \mu \mathrm{mol}$ (photons) $\mathrm{m}^{-2} \mathrm{~s}^{-1}$; for dark respiratory rate measurement, the PFD was set to 0 $\mu \mathrm{mol} \mathrm{m} \mathrm{m}^{-2} \mathrm{~s}^{-1}$. Each time when the gas exchange rate readings were stabilized, data were logged after matching the two infrared gas analyzers (IRGAs).

The rice cultivar $\mathrm{YY} 17$ was used for photosynthetic light and $\mathrm{CO}_{2}$ response curve measurements 10 days after heading in 2016. For photosynthetic light response curve measurement, the $\mathrm{CO}_{2}$ concentration was set to $400 \mu \mathrm{mol} \mathrm{mol}^{-1}$, the flow rate was set to $700 \mu \mathrm{mol} \mathrm{s}^{-1}$; and the light levels were manually changed in the following sequence: 2000, 1500, 1000, 700, 500, 300, 200, 100, 50, 25 and $0 \mu$ mol (photons) $\mathrm{m}^{-2} \mathrm{~s}^{-1}$ during measurement. Panicles were maintained in the cuvette at each light level for about 4 min before photosynthetic rate was stabilized and recorded. For photosynthetic $\mathrm{CO}_{2}$ response curve measurement, the PFD was set to $2000 \mu \mathrm{mol}$ (photons) $\mathrm{m}^{-2} \mathrm{~s}^{-1}$, the flow rate was set to $700 \mu \mathrm{mol} \mathrm{s} \mathrm{s}^{-1}$, and the reference $\mathrm{CO}_{2}$ concentration was set to $400 \mu \mathrm{mol} \mathrm{mol}{ }^{-1}$. The panicles were maintained under the above described condition for $15 \mathrm{~min}$. Then, the $\mathrm{CO}_{2}$ concentrations were manually changed in the following sequence: $400,300,150,100$ and $50 \mu \mathrm{mol} \mathrm{mol}^{-1}$ during measurement. Panicles were maintained in the cuvette at each $\mathrm{CO}_{2}$ concentration for about 4 min before photosynthetic rate was stabilized and recorded. Next, the 
$\mathrm{CO}_{2}$ concentration was set back to $400 \mu \mathrm{mol} \mathrm{m} \mathrm{m}^{-2} \mathrm{~s}^{-1}$ and maintained at that concentration for $15 \mathrm{~min}$.

Finally, the $\mathrm{CO}_{2}$ concentrations were manually changed in the following sequence: $600,900,1200,1500$ and $1800 \mu \mathrm{mol} \mathrm{mol}^{-1}$. Again, panicles were maintained in the cuvette at each $\mathrm{CO}_{2}$ concentration for about 4 min before photosynthetic rate was stabilized and recorded.

\section{Calculation of panicle area and flag area}

Areas of spikelets and branches in a panicle were calculated to obtain the total area of a panicle. Specifically, the non-degraded green spikelets were firstly detached from the panicle 5 days after heading; then, these spikelets were scanned with an Epson Perfection V300 Photo scanner (Epson, Tokyo, Japan; Fig. S1a). The areas of spikelets in the scanned images were obtained by image processing using ImageJ (US National Institutes of Health, Bethesda, USA). The flag leaf area was obtained in the same way (Fig. S1c).

The spikelet-less panicles were then spread out, scanned with an Epson Perfection V300 Photo scanner as well (Epson, Tokyo, Japan; Fig. S1b). The projected area of branches was obtained through image processing using ImageJ (US National Institutes of Health, Bethesda, USA). Branches were assumed as cylinders, and single-sided surface area of all branches on a panicle $S$ was then calculated as:

\section{$S=s_{\mathrm{bp}}{ }^{*} \pi / 2$ Eqn. 1}

in which $s_{\mathrm{bp}}$ is the projected area of branches. Single-sided surface area of a whole panicle was calculated as a sum of the area of branches and the area of all spikelets.

\section{Agronomic traits measurement}

Five of the twenty labeled panicles were sampled and stored in envelops individually for each cultivar at harvest. The panicle length was measured, and then the panicles were put in an oven for drying. The temperature of the oven was maintained at $110^{\circ} \mathrm{C}$ for 1 hour, and then switched to $70^{\circ} \mathrm{C}$ and maintained for 3 days until samples were completely dried. Dry weight of each panicle was measured with an electronic balance AL104 (JB / T, METTLER TOLEDO, USA). The panicles were then threshed to determine the total spikelet number and filled grain number. The weight of all filled grains were measured to determine the 1000-grain weight.

\section{Data Analysis}

Statistical analyses were carried out using R-project (version 3.6.2). One-way analysis of variance (ANOVA) and the Scheffe post-hoc test were used to compare data at a level of $5 \%$. The Pearson correlation coefficients between panicle photosynthetic gas exchange parameters and grain yield related agronomic traits were calculated using the R package (Corrplot; version 0.84).

\section{Declarations}




\section{Ethics approval and consent to participate}

Not applicable.

\section{Consent for publication}

Not applicable.

\section{Availability of data and material}

All data generated or analyzed during this study are included in the article and in Additional file 1.

\section{Competing interests}

The authors declare that they have no conflict of interest.

\section{Funding}

This research was financially supported by the CAS strategic priority research program of the Chinese Academy of Sciences (XDB27020105), National Science Foundation of China (grant No. 31870214), National Natural Science Foundation of China (grant No. 31871704) and Hunan Provincial Natural Science Foundation of China (grant No. 2018JJ2286).

\section{Authors' contributions}

XGZ and TGC conceived the research plan; TGC and HLZ managed the experiments; TGC analyzed the data; TGC and XGZ drafted the article; QFS, CX, SC and MQ provided technical assistance and constructive suggestions for the P-chamber building, field experiment and manuscript improvement; all authors discussed the results and contributed to the final manuscript.

Acknowledgements: The authors thank Xiaojuan Fan, Yi Xiao, Han Jing and Faming Chen for assistance in field experiments and helpful comments and suggestions on an early draft of the manuscript.

\section{Abbreviations}

9311, an indica inbred cultivar Yang-Dao 6; $A_{\text {gross }}$ per unit area, gross panicle photosynthetic rate on an area basis $\left(\mu \mathrm{mol} \mathrm{m} \mathrm{m}^{-2} \mathrm{~s}^{-1}\right) ; A_{\text {net }}$ per unit area, net panicle photosynthetic rate on an area basis $\left(\mu \mathrm{mol} \mathrm{m} \mathrm{m}^{-2} \mathrm{~s}^{-}\right.$ $\left.{ }^{1}\right) ; \mathrm{C}_{\mathrm{a}}$, ambient air $\mathrm{CO}_{2}$ concentration $\left(\mu \mathrm{mol} \mathrm{mol}{ }^{-1}\right) ; \mathrm{CY} 1000$, an indica super high yield hybrid rice cultivar Chao-You 1000; Panicle $A_{\text {net, }}$, net photosynthetic rate of a whole panicle ( $\mathrm{nmol} \mathrm{s}^{-1}$ ); Panicle $A_{\text {gross }}$ gross photosynthetic rate of a whole panicle $\left(\mathrm{nmol} \mathrm{s}^{-1}\right)$; Panicle $R_{\mathrm{p}}$, respiratory rate of a whole panicle ( $\mathrm{nmol} \mathrm{s}$ $\left.{ }^{1}\right)$; P-chamber, the custom-built chamber for panicle photosynthetic gas exchange rate measurements; PFD, photon flux density $\left(\mu \mathrm{mol} \mathrm{m} \mathrm{m}^{-2} \mathrm{~s}^{-1}\right) ; R_{\mathrm{d}}$ per unit area, panicle respiratory rate on an area basis $(\mu \mathrm{mol}$ $\mathrm{m}^{-2} \mathrm{~s}^{-1}$ ); Spikelet $A_{\text {net, }}$ net panicle photosynthetic rate on a spikelet basis $\left(\mathrm{nmol} \mathrm{s}{ }^{-1}\right.$ ); Spikelet $A_{\text {gross }}$ gross 
panicle photosynthetic rate on a spikelet basis $\left(\mathrm{nmol} \mathrm{s}^{-1}\right)$; Spikelet $R_{\mathrm{d}}$, panicle respiratory rate on a spikelet basis $\left(\mathrm{nmol} \mathrm{s}^{-1}\right)$; SY 63, a traditional indica hybrid cultivar Shan-You 63; XS134, an elite japonica inbred rice cultivar Xiu-Shui 134; YLY900, an indica super high yield hybrid rice cultivar Y-Liang-You 900; YY17, a japonica-indica hybrid rice cultivar Yong-You 17; YY538, a japonica-indica hybrid rice cultivar Yong-You 538.

\section{References}

1. Yoshida, S., Physiological aspects of grain yield. Annual Review of Plant Physiology, 1972. 23(1): p. 437-464.

2. Gebbing, T. and H. Schnyder, Pre-anthesis reserve utilization for protein and carbohydrate synthesis in grains of wheat. Plant Physiology, 1999. 121(3): p. 871-878.

3. Ramasamy, S., H.F.M. tenBerge, and S. Purushothaman, Yield formation in rice in response to drainage and nitrogen application. Field Crops Research, 1997. 51(1-2): p. 65-82.

4. Yang, J. and J. Zhang, Grain filling of cereals under soil drying. New Phytologist, 2006. 169(2): p. 223-236.

5. Yoshida, S., Fundamentals of rice crop science. 1981: Los Banos, Philippines: International Rice Research Institute.

6. Blum, A., Photosynthesis and transpiration in leaves and ears of wheat and barley varieties. Journal of Experimental Botany, 1985. 36(3): p. 432-440.

7. Grundbacher, F.J., The physiological function of the cereal awn. The Botanical Review, 1963. 29(3): p. 366-381.

8. Imaizumi, N., et al., Changes in the rate of photosynthesis during grain filling and the enzymatic activities associated with the photosynthetic carbon metabolism in rice panicles. Plant and Cell Physiology, 1990. 31(6): p. 835-844.

9. Bremner, P.M. and H.M. Rawson, Fixation of ${ }^{14} \mathrm{CO}_{2}$ by flowering and non-flowering glumes of the wheat ear, and the pattern of transport of label to individual grains. Australian Journal of Biological Sciences, 1972. 25(5): p. 921-930.

10. Noodén, L.D. and J.P. Penney, Correlative controls of senescence and plant death in Arabidopsis thaliana (Brassicaceae). Journal of Experimental Botany, 2001. 52(364): p. 2151-2159.

11. Jia, S., et al., Response of wheat ear photosynthesis and photosynthate carbon distribution to water deficit. Photosynthetica, 2015. 53(1): p. 95-109.

12. Hu, L., et al., Photosynthetic characteristics of non-foliar organs in main $C_{3}$ cereals. Physiologia Plantarum, 2019. 166(1): p. 226-239.

13. Brazel, A.J. and D.S. Ó'Maoiléidigh, Photosynthetic activity of reproductive organs. Journal of Experimental Botany, 2019. 70(6): p. 1737-1754. 
14. Sanchez-Bragado, R., et al., New avenues for increasing yield and stability in $C_{3}$ cereals: exploring ear photosynthesis. Current Opinion in Plant Biology, 2020.

15. Simkin, A.J., et al., Photosynthesis in non-foliar tissues: implications for yield. The Plant Journal, 2020. 101: p. 1001-1015.

16. Araus, J.L., et al., Ear photosynthesis, carbon isotope discrimination and the contribution of respiratory $\mathrm{CO}_{2}$ to differences in grain mass in durum wheat. Plant, Cell \& Environment, 1993. 16(4): p. 383-392.

17. Maydup, M.L., et al., The contribution of ear photosynthesis to grain filling in bread wheat (Triticum aestivum L.). Field Crops Research, 2010. 119(1): p. 48-58.

18. Wang, Y.-q., et al., Contribution of ear photosynthesis to grain yield under rainfed and irrigation conditions for winter wheat cultivars released in the past 30 years in North China Plain. Journal of Integrative Agriculture, 2016. 15(10): p. 2247-2256.

19. Kriedemann, P., The photosynthetic activity of the wheat ear. Annals of Botany, 1966. 30(3): p. 349363.

20. Evans, L. and H. Rawson, Photosynthesis and respiration by the flag leaf and components of the ear during grain development in wheat. Australian Journal of Biological Sciences, 1970. 23(2): p. 245254.

21. Sanchez-Bragado, R., et al., Relative contribution of shoot and ear photosynthesis to grain filling in wheat under good agronomical conditions assessed by differential organ delta13C. Journal of Experimental Botany, 2014. 65(18): p. 5401-13.

22. Sanchez-Bragado, R., et al., Photosynthetic contribution of the ear to grain filling in wheat: a comparison of different methodologies for evaluation. Journal of experimental botany, 2016. 67(9): p. 2787-2798.

23. Parry, M.A.J., et al., Raising yield potential of wheat. II. Increasing photosynthetic capacity and efficiency. Journal of Experimental Botany, 2011. 62(2): p. 453-467.

24. Yoshida, S. and J.H. Cock, Growth performance of an improved rice variety in the tropics. International Rice Communication Newsletter (FAO), 1971. 20: p. 1-15.

25. Tsuno, Y., et al., Studies on $\mathrm{CO}_{2}$ uptake and $\mathrm{CO}_{2}$ evolution in each part of crop plants. II. Photosynthetic activity in the leaf sheath and ear of rice plant. Proceedings of the Crop Science Society of Japan, 1975. 44: p. 287-292.

26. Takeda, $\mathrm{T}$. and H. Maruta, Studies on $\mathrm{CO}_{2}$ exchange in crop plants IV: Roles played by the various parts of the photosynthetic organs of rice plant in producing grains during the ripening period. Japanese Journal of Crop Science, 1956. 24: p. 181-184.

27. Setter, T., et al., Possibility of increasing yield potential of rice by reducing panicle height in the canopy. I. Effects of panicles on light interception and canopy photosynthesis. Functional Plant Biology, 1995. 22(3): p. 441-451. 
28. Xu, M., et al., An active supercomplex of NADPH dehydrogenase mediated cyclic electron flow around Photosystem I from the panicle chloroplast of Oryza sativa. Acta Biochimica Et Biophysica Sinica, 2014. 46(9): p. 757.

29. Chen, T., et al., Expression of proteins in superior and inferior spikelets of rice during grain filling under different irrigation regimes. Proteomics, 2016. 16(1): p. 102-121.

30. Duwayri, M., Effect of flag leaf and awn removal on grain yield and yield components of wheat grown under dryland conditions. Field Crops Research, 1984. 8(4): p. 307-313.

31. Tambussi, E.A., et al., The photosynthetic role of ears in $C_{3}$ cereals: metabolism, water use efficiency and contribution to grain yield. Critical Reviews in Plant Sciences, 2007. 26(1): p. 1-16.

32. Chanishvili, S.S., et al., Defoliation, photosynthetic rates, and assimilate transport in grapevine plants. Russian Journal of Plant Physiology, 2005. 52(4): p. 448-453.

33. Eyles, A., et al., Whole-plant versus leaf-level regulation of photosynthetic responses after partial defoliation in Eucalyptus globulus saplings. Journal of Experimental Botany, 2013. 64(6): p. 16251636.

34. Zhang, Y.-h., et al., Effect of source-sink manipulation on photosynthetic characteristics of flag leaf and the remobilization of dry mass and nitrogen in vegetative organs of wheat. Journal of Integrative Agriculture, 2014. 13(8): p. 1680-1690.

35. Frey-Wyssling, A. and M.S. Buttrose, Photosynthesis in the ear of barley. Nature, 1959. 184(4704): p. 2031-2032.

36. Cheung, F., Yield: The search for the rice of the future. Nature, 2014. 514(7524): p. S60-S61.

37. Knoppik, D., H. Selinger, and A. Ziegler-Jöns, Differences between the flag leaf and the ear of a spring wheat cultivar (Triticum aestivum $\mathrm{cv}$. Arkas) with respect to the $\mathrm{CO}_{2}$ response of assimilation, respiration and stomatal conductance. Physiologia Plantarum, 1986. 68(3): p. 451-457.

38. Tambussi, E.A., S. Nogués, and J.L. Araus, Ear of durum wheat under water stress: water relations and photosynthetic metabolism. Planta, 2005. 221(3): p. 446-458.

39. Ishihara, K., E. Kiyota, and N. Imaizumi, Transpiration and photosynthesis characteristics of the panicle in comparison with the flag leaf in the rice plant. Japanese Journal of Crop Science, 1990. 59(2): p. 321-326.

40. Lu, Q. and C. Lu, Photosynthetic pigment composition and photosystem II photochemistry of wheat ears. Plant Physiology and Biochemistry, 2004. 42(5): p. 395-402.

41. Chang, S., et al., Photosynthetic and agronomic traits of an elite hybrid rice Y-Liang-You 900 with a record-high yield. Field Crops Research, 2016. 187: p. $49-57$.

42. $\mathrm{Gu}, \mathrm{J}$. , et al., Can exploiting natural genetic variation in leaf photosynthesis contribute to increasing rice productivity? A simulation analysis. Plant, Cell and Environment, 2014. 37(1): p. 22-34.

43. Murchie, E.H., et al., Are there associations between grain-filling rate and photosynthesis in the flag leaves of field-grown rice? Journal of Experimental Botany, 2002. 53(378): p. 2217-2224. 
44. Chang, T.-G., et al., A three-dimensional canopy photosynthesis model in rice with a complete description of the canopy architecture, leaf physiology, and mechanical properties. Journal of Experimental Botany, 2019. ery430.

45. Xu, Z.J., et al., Design principles and parameters of rice ideal panicle type. Chinese Science Bulletin, 2005. 50(19): p. 2253-2256.

46. Yuan, L., Progress in super-hybrid rice breeding. The Crop Journal, 2017. 5(2): p. 100-102.

47. Zhang, G.H., et al., LSCHL4 from japonica cultivar, which is allelic to NAL 1, increases yield of indica super rice 93-11. Molecular Plant, 2014. 7(8): p. 1350-1364.

48. Fujita, D., et al., NAL 1 allele from a rice landrace greatly increases yield in modern indica cultivars. Proceedings of the National Academy of Sciences of the United States of America, 2013. 110(51): $p$. 20431-20436.

49. van Dongen, J.T., et al., Phloem import and storage metabolism are highly coordinated by the low oxygen concentrations within developing wheat seeds. Plant Physiology, 2004. 135(3): p. 1809-1821.

50. Pearson, J.N., et al., Manipulation of xylem transport affects $Z n$ and Mn transport into developing wheat grains of cultured ears. Physiologia Plantarum, 1996. 98(2): p. 229-234.

51. Maydup, M.L., et al., The contribution of the awns of bread wheat (Triticum aestivum L.) to grain filling: Responses to water deficit and the effects of awns on ear temperature and hydraulic conductance. Field Crops Research, 2014. 167: p. 102-111.

52. Simpson, R.J., H. Lambers, and M.J. Dalling, Nitrogen Redistribution during Grain-Growth in Wheat (Triticum aestivum L.) 4. Development of a Quantitative Model of the Translocation of Nitrogen to the Grain. Plant Physiology, 1983. 71(1): p. 7-14.

53. Shi, Z., et al., Dissection of mechanisms for high yield in two elite rice cultivars. Field Crops Research, 2019. 241: p. 107563.

54. Liu, E., et al., Favorable alleles of GRAIN-FILLING RATE1 increase the grain-filling rate and yield of rice. Plant Physiology, 2019. 181(3): p. 1207-1222.

\section{Tables}

Table 1. Panicle photosynthetic gas exchange parameters of the rice cultivars measured 5 days after heading. Data presented are mean values with s.d. ( $\mathrm{n}=3$ in year 2015; $\mathrm{n}=5$ in year 2016). Data followed by different letters are statistically different at $p$-value $<0.05$. 


\begin{tabular}{|c|c|c|c|c|c|c|c|}
\hline Year & Cultivar & $\begin{array}{l}\text { Panicle } A_{\text {net }} \\
\left.(\mathrm{nmol} \mathrm{s})^{-1}\right)\end{array}$ & $\begin{array}{l}\text { Panicle } A_{\text {gross }} \\
\left(\mathrm{nmol} \mathrm{s}^{-1}\right)\end{array}$ & $\begin{array}{l}\text { Panicle } R_{\mathrm{d}} \\
\left.(\mathrm{nmol} \mathrm{s})^{-1}\right)\end{array}$ & $\begin{array}{l}\text { Spikelet } A_{\text {net }} \\
\left(\mathrm{nmol} \mathrm{s}{ }^{-1}\right)\end{array}$ & $\begin{array}{l}\text { Spikelet } A_{\text {gross }} \\
\left(\mathrm{nmol} \mathrm{s}^{-1}\right)\end{array}$ & $\begin{array}{l}\text { Spikelet } R_{\mathrm{d}} \\
\left.(\mathrm{nmol} \mathrm{s})^{-1}\right)\end{array}$ \\
\hline \multirow[t]{5}{*}{2015} & YLY900 & $12 \pm 2.4 a$ & $49 \pm 2.8 a$ & $37 \pm 1.5 a$ & $0.035 \pm 0.003 a$ & $0.147 \pm 0.011 b$ & $0.111 \pm 0.013 a$ \\
\hline & CY1000 & $7.2 \pm 1.3 \mathrm{~b}$ & $43.6 \pm 7 a$ & $36.4 \pm 7.3 \mathrm{a}$ & $0.015 \pm 0.004 b$ & $0.091 \pm 0.005 c$ & $0.075 \pm 0.005 b$ \\
\hline & SY63 & $11.8 \pm 2.2 \mathrm{a}$ & $42.8 \pm 2.7 a$ & $31 \pm 2.8 a$ & $0.051 \pm 0.012 \mathrm{a}$ & $0.185 \pm 0.014 a$ & $0.133 \pm 0.007 a$ \\
\hline & 9311 & $10.9 \pm 1.4 \mathrm{ab}$ & $46 \pm 3.4 \mathrm{a}$ & $35 \pm 3.9 a$ & $0.044 \pm 0.009 a$ & $0.182 \pm 0.007 \mathrm{ab}$ & $0.138 \pm 0.003 a$ \\
\hline & XS134 & $2.7 \pm 1.1 \mathrm{c}$ & $18.1 \pm 3.4 \mathrm{~b}$ & $15.4 \pm 2.5 b$ & $0.012 \pm 0.005 b$ & $0.078 \pm 0.022 \mathrm{c}$ & $0.067 \pm 0.017 \mathrm{~b}$ \\
\hline \multirow[t]{7}{*}{2016} & YLY900 & $7.3 \pm 2.4 \mathrm{~b}$ & $47.5 \pm 4.1 \mathrm{a}$ & $40.2 \pm 5.6 a$ & $0.021 \pm 0.007 \mathrm{bc}$ & $0.136 \pm 0.011 b$ & $0.115 \pm 0.014 \mathrm{~b}$ \\
\hline & CY1000 & $6.9 \pm 2.2 b$ & $44.3 \pm 4 \mathrm{ab}$ & $37.4 \pm 4.6 \mathrm{ab}$ & $0.017 \pm 0.006 \mathrm{bc}$ & $0.106 \pm 0.013 \mathrm{bc}$ & $0.089 \pm 0.01 \mathrm{bc}$ \\
\hline & SY63 & $15 \pm 3 a$ & $49.6 \pm 4.3 \mathrm{a}$ & $34.6 \pm 5.3 \mathrm{ab}$ & $0.075 \pm 0.016 a$ & $0.248 \pm 0.021 \mathrm{a}$ & $0.172 \pm 0.023 a$ \\
\hline & 9311 & $11.9 \pm 2.6 \mathrm{ab}$ & $53.6 \pm 3.9 a$ & $45.5 \pm 4.5 \mathrm{a}$ & $0.052 \pm 0.009 a$ & $0.243 \pm 0.005 a$ & $0.205 \pm 0.021 \mathrm{a}$ \\
\hline & XS134 & $-3.3 \pm 3.4 \mathrm{c}$ & $17.1 \pm 4.4 \mathrm{~d}$ & $20.3 \pm 6.4 \mathrm{c}$ & $-0.014 \pm 0.014 d$ & $0.075 \pm 0.018 \mathrm{~cd}$ & $0.089 \pm 0.026 \mathrm{bc}$ \\
\hline & YY538 & $-0.4 \pm 2.4 \mathrm{c}$ & $25.8 \pm 4.7 \mathrm{~cd}$ & $26.2 \pm 4.1 \mathrm{bc}$ & $-0.001 \pm 0.006 \mathrm{~cd}$ & $0.06 \pm 0.009 d$ & $0.062 \pm 0.011 \mathrm{c}$ \\
\hline & YY17 & $9.3 \pm 3.1 \mathrm{ab}$ & $36 \pm 5.8 \mathrm{bc}$ & $26.8 \pm 5.6 b c$ & $0.024 \pm 0.009 b$ & $0.091 \pm 0.01 \mathrm{~cd}$ & $0.068 \pm 0.01 \mathrm{c}$ \\
\hline
\end{tabular}

Table 2. The area of a flag leaf and the areas of all spikelets and branches in a panicle for different rice cultivars 5 days after heading $(n=5)$. Data measured in 2016. Data presented are mean values with s.d. $(\mathrm{n}=5)$. Data followed by different letters are statistically different at $p$-value $<0.05$. Note that areas presented are single side based.

\begin{tabular}{|c|c|c|c|c|c|}
\hline Name & $\begin{array}{l}\text { Spikelets area } \\
\left(\mathrm{cm}^{2}\right)\end{array}$ & $\begin{array}{l}\text { Branches area } \\
\left(\mathrm{cm}^{2}\right)\end{array}$ & $\begin{array}{l}\text { Panicle area } \\
\left(\mathrm{cm}^{2}\right)\end{array}$ & $\begin{array}{l}\text { Branches : Panicle } \\
\text { area ratio }\end{array}$ & $\begin{array}{l}\text { Flag leaf } \\
\text { area }\left(\mathrm{cm}^{2}\right)\end{array}$ \\
\hline YLY900 & $79.7 \pm 6.5 a$ & $34.6 \pm 2.8 \mathrm{a}$ & $115.5 \pm 11.7 \mathrm{ab}$ & $0.3 \pm 0.01 \mathrm{~b}$ & $73.8 \pm 11 b$ \\
\hline CY1000 & $74.7 \pm 7.9 \mathrm{a}$ & $28.4 \pm 1.4 \mathrm{~b}$ & $120.7 \pm 13 a$ & $0.28 \pm 0.02 \mathrm{~cd}$ & $88.1 \pm 11.3 a$ \\
\hline SY63 & $47 \pm 4.1 \mathrm{bc}$ & $23 \pm 1.9 \mathrm{~cd}$ & $74.3 \pm 7.2 \mathrm{~d}$ & $0.33 \pm 0 a$ & $61.9 \pm 10.9 \mathrm{~cd}$ \\
\hline 9311 & $54.2 \pm 4.2 \mathrm{~b}$ & $21.2 \pm 1.6 \mathrm{~d}$ & $71.6 \pm 6.8 \mathrm{~d}$ & $0.28 \pm 0 \mathrm{bc}$ & $56.2 \pm 12.1 \mathrm{de}$ \\
\hline XS134 & $39 \pm 3.5 c$ & $12.6 \pm 1.4 \mathrm{e}$ & $56.3 \pm 8.1 \mathrm{e}$ & $0.24 \pm 0.03 d$ & $32.6 \pm 4.4 \mathrm{f}$ \\
\hline YY538 & $69.5 \pm 3.7 \mathrm{a}$ & $26.8 \pm 1.6 \mathrm{bc}$ & $109 \pm 9.1 b c$ & $0.28 \pm 0.02 \mathrm{bcd}$ & $48.7 \pm 8 e$ \\
\hline YY17 & $72.5 \pm 6.7 a$ & $25.6 \pm 3.1 \mathrm{bcd}$ & $106.3 \pm 8.7 \mathrm{c}$ & $0.26 \pm 0.01 \mathrm{~cd}$ & $72.3 \pm 8.4 \mathrm{bc}$ \\
\hline
\end{tabular}

Table 3. Panicle photosynthetic gas exchange parameters on an area basis for different rice cultivars 5 days after heading $(n=5)$. Data were measured in 2016. Data presented are mean values with s.d. $(\mathrm{n}=5)$. Data followed by different letters are statistically different at $p$-value $<0.05$. 


\begin{tabular}{llll}
\hline Name & $\begin{array}{l}A_{\text {net per unit area }} \\
\left(\mu \mathrm{mol} \mathrm{m} \mathrm{s}^{-1}\right)\end{array}$ & $\begin{array}{l}A_{\text {gross per unit area }}\left(\mu \mathrm{mol} \mathrm{m} \mathrm{s}^{-1}\right) \\
R_{\text {d per unit area }} \\
\left(\mu \mathrm{mol} \mathrm{m} \mathrm{s}^{-1}\right)\end{array}$ \\
\hline YLY900 & $0.7 \pm 0.2 \mathrm{~cd}$ & $4.2 \pm 0.4 \mathrm{~b}$ & $3.6 \pm 0.4 \mathrm{bc}$ \\
CY1000 & $0.6 \pm 0.2 \mathrm{~cd}$ & $3.6 \pm 0.4 \mathrm{bc}$ & $3 \pm 0.3 \mathrm{bcd}$ \\
SY63 & $2.2 \pm 0.5 \mathrm{a}$ & $7.2 \pm 0.6 \mathrm{a}$ & $5 \pm 0.7 \mathrm{ab}$ \\
9311 & $1.6 \pm 0.3 \mathrm{ab}$ & $7.2 \pm 0.1 \mathrm{a}$ & $6.1 \pm 0.6 \mathrm{a}$ \\
XS134 & $-0.6 \pm 0.6 \mathrm{e}$ & $3 \pm 0.7 \mathrm{~cd}$ & $3.6 \pm 1.1 \mathrm{bc}$ \\
YY538 & $0 \pm 0.2 \mathrm{de}$ & $2.1 \pm 0.3 \mathrm{~d}$ & $2.1 \pm 0.4 \mathrm{~d}$ \\
YY17 & $0.9 \pm 0.3 \mathrm{bc}$ & $3.5 \pm 0.4 \mathrm{bc}$ & $2.6 \pm 0.4 \mathrm{~cd}$ \\
\hline
\end{tabular}

Table 4. Grain yield related agronomic traits of the rice cultivars at harvest. Data presented are mean values with s.d. $(n=5)$. Data followed by different letters are statistically different at $p$-value $<0.05$.

\begin{tabular}{|c|c|c|c|c|c|c|c|}
\hline Year & Cultivar & $\begin{array}{l}\text { Spikelet } \\
\text { number }\end{array}$ & $\begin{array}{l}\text { Panicle length } \\
(\mathrm{cm})\end{array}$ & $\begin{array}{l}\text { Spikelet } \\
\text { density }\end{array}$ & $\begin{array}{l}\text { 1000-grain weight } \\
\text { (g) }\end{array}$ & $\begin{array}{l}\text { Grain setting } \\
\text { rate }\end{array}$ & $\begin{array}{l}\text { Panicle weight } \\
\text { (g) }\end{array}$ \\
\hline \multirow[t]{5}{*}{2015} & YLY900 & $356 \pm 24 b$ & $28.1 \pm 1.5 a$ & $13.1 \pm 1.4 \mathrm{~b}$ & $22.9 \pm 0.7 d$ & $0.84 \pm 0.07 \mathrm{bc}$ & $7.4 \pm 1 b$ \\
\hline & CY1000 & $444 \pm 30 a$ & $21.8 \pm 1.1 \mathrm{c}$ & $21 \pm 2.4 \mathrm{a}$ & $21.6 \pm 0.7 d$ & $0.8 \pm 0.05 c$ & $8.7 \pm 0.5 a$ \\
\hline & SY63 & $231 \pm 21 c$ & $27.6 \pm 0.9 a$ & $8.4 \pm 0.6 c$ & $28.2 \pm 1.3 \mathrm{~b}$ & $0.92 \pm 0.04 \mathrm{ab}$ & $6.4 \pm 0.6 \mathrm{bc}$ \\
\hline & 9311 & $234 \pm 40 \mathrm{c}$ & $24.5 \pm 1 b$ & $9.5 \pm 1.3 \mathrm{c}$ & $30.7 \pm 0.4 a$ & $0.97 \pm 0.02 \mathrm{a}$ & $7.2 \pm 1.1 \mathrm{~b}$ \\
\hline & XS134 & $253 \pm 14 c$ & $17.1 \pm 0.7 d$ & $14.8 \pm 0.9 \mathrm{~b}$ & $25.2 \pm 0.8 c$ & $0.74 \pm 0.08 c$ & $5.7 \pm 0.4 \mathrm{c}$ \\
\hline \multirow[t]{7}{*}{2016} & YLY900 & $359 \pm 36 b$ & $32.7 \pm 0.6 \mathrm{a}$ & $10.9 \pm 0.9 \mathrm{~d}$ & $22.2 \pm 4 c$ & $0.83 \pm 0.09 \mathrm{bc}$ & $7 \pm 0.9 \mathrm{ab}$ \\
\hline & CY1000 & $410 \pm 44 a$ & $26.5 \pm 1 c$ & $13.8 \pm 2.3 \mathrm{bc}$ & $21.8 \pm 0.5 c$ & $0.81 \pm 0.03 c$ & $8.1 \pm 0.5 a$ \\
\hline & SY63 & $216 \pm 21 c$ & $30.5 \pm 1.2 b$ & $6.7 \pm 0.5 e$ & $29.6 \pm 1.1 \mathrm{ab}$ & $0.96 \pm 0.01 \mathrm{ab}$ & $6.4 \pm 0.4 b$ \\
\hline & 9311 & $211 \pm 20 c$ & $27.2 \pm 1.3 c$ & $8.2 \pm 0.3 e$ & $30.8 \pm 1.6 a$ & $0.96 \pm 0.02 \mathrm{a}$ & $6.3 \pm 0.7 \mathrm{bc}$ \\
\hline & XS134 & $222 \pm 32 c$ & $18.2 \pm 1.5 \mathrm{e}$ & $11.2 \pm 1.1 \mathrm{~cd}$ & $24.1 \pm 0.3 \mathrm{bc}$ & $0.79 \pm 0.05 c$ & $4.7 \pm 0.3 \mathrm{c}$ \\
\hline & YY538 & $420 \pm 35 a$ & $21.6 \pm 0.9 d$ & $17.2 \pm 0.7 a$ & $20.5 \pm 1.3 c$ & $0.77 \pm 0.06 c$ & $6.9 \pm 0.7 \mathrm{ab}$ \\
\hline & YY17 & $403 \pm 33 a$ & $23.9 \pm 1.1 \mathrm{~d}$ & $15.5 \pm 0.9 \mathrm{ab}$ & $22.3 \pm 1 \mathrm{c}$ & $0.84 \pm 0.08 a b c$ & $7.4 \pm 0.6 \mathrm{ab}$ \\
\hline
\end{tabular}

Table 5. Estimated ratios of light saturated gross photosynthetic rates between a panicle and a flag leaf 5 days after heading in seven rice cultivars. Data measured in $2016(\mathrm{n}=5)$.

\begin{tabular}{llll}
\hline Name & $\begin{array}{l}A_{\text {gross }} \text { of a flag leaf } \\
\left(\mathrm{nmol} \mathrm{s}^{-1}\right)\end{array}$ & $\begin{array}{l}A_{\text {gross }} \text { of a panicle } \\
\left(\mathrm{nmol} \mathrm{s}^{-1}\right)\end{array}$ & P/FL $A_{\text {gross }}$ \\
\hline YLY900 & 185 & 48 & 0.26 \\
CY1000 & 220 & 44 & 0.2 \\
SY63 & 155 & 50 & 0.32 \\
9311 & 141 & 54 & 0.38 \\
XS134 & 82 & 17 & 0.21 \\
YY538 & 122 & 26 & 0.21 \\
YY17 & 181 & 36 & 0.2 \\
\hline
\end{tabular}


Notes: $A_{\text {gross }}$ of a flag leaf, estimated light saturated gross photosynthetic rate of a whole flag leaf by assuming a constant light saturated photosynthetic rate of $25 \mu \mathrm{mol} \mathrm{m} \mathrm{m}^{-2} \mathrm{~s}^{-1}$ (the leaf area data was taken from Table 2); $A_{\text {gross }}$ of a panicle, light saturated gross photosynthetic rate of a whole panicle (data was taken from Table 1); P/FL $A_{\text {gross, }}$ the ratio between light saturated gross photosynthetic rate of a panicle and that of a flag leaf.

\section{Figures}

A
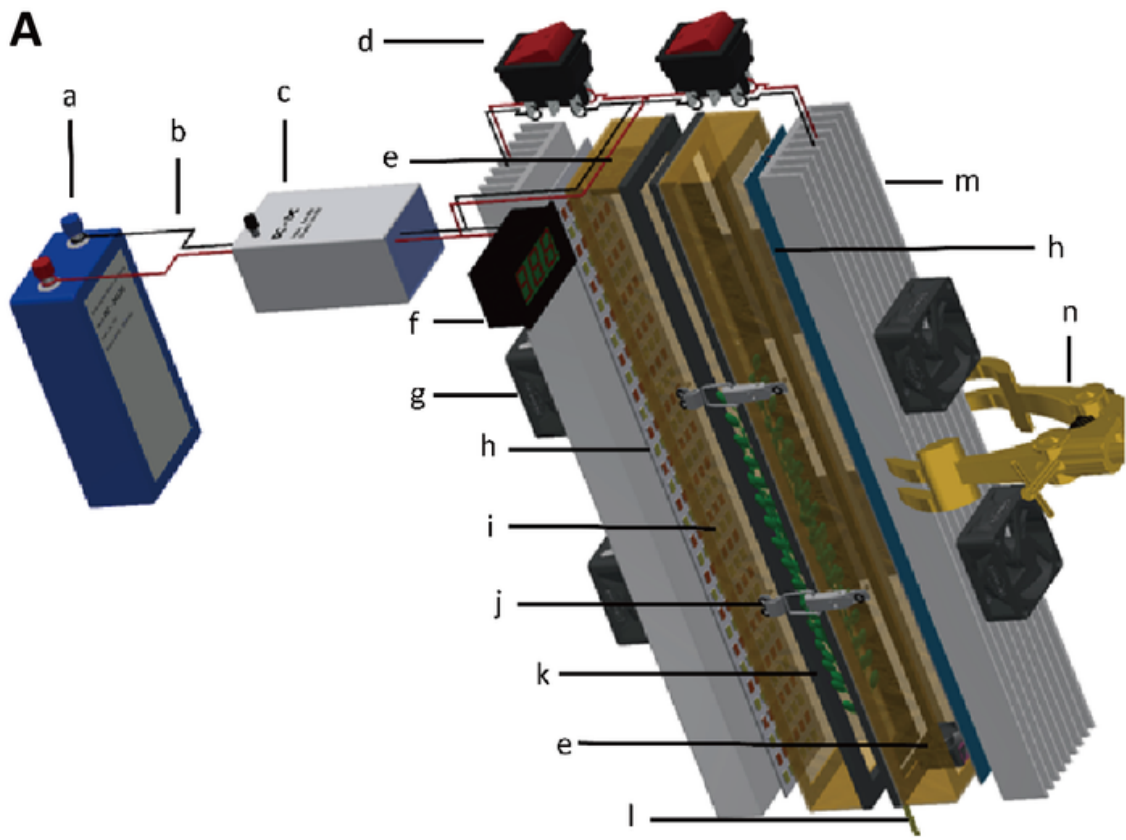
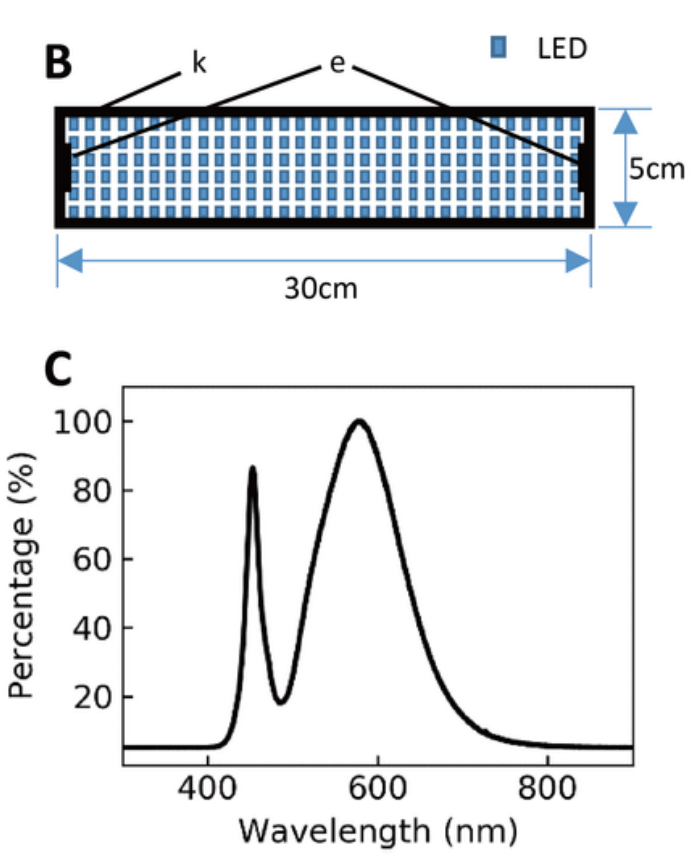
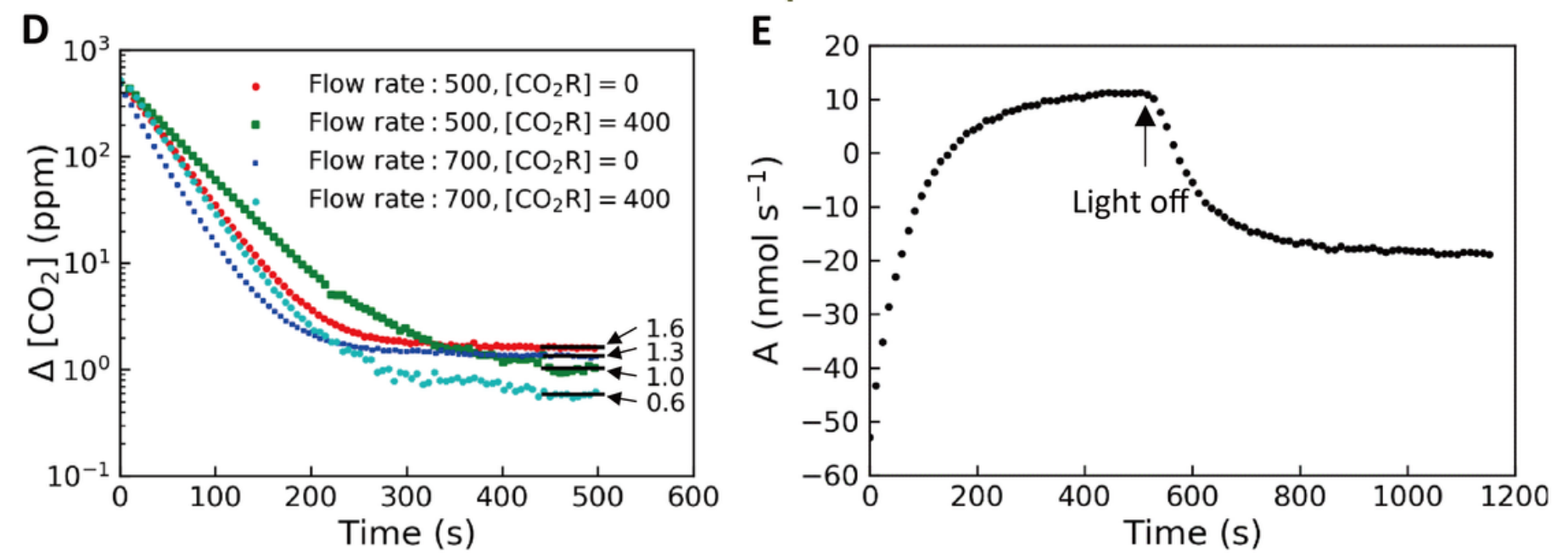

Figure 1.

\section{Figure 1}

A custom-built panicle photosynthesis chamber (P-chamber) for panicle gas exchange measurements. a, An illustration of how the P-chamber works together with the gas analyzer Li-6400 to measure the photosynthetic and respiratory rates of a rice panicle. b, The setting of a P-chamber in a paddy field. c, An 
illustration of design of the P-chamber. $d, A$ top-down view of the inner part of the P-chamber. e, The homogeneity of PFD in the chamber. $f$, Spectrum of the LED light source. $g$, The difference between the $\mathrm{CO} 2$ concentration in the P-chamber and the set $\mathrm{CO} 2$ concentration ([CO2R]) in the reference pipe at different time after closure of the P-chamber. $h$, Recorded photosynthetic gas exchange rate of a rice panicle under a photon flux density (PFD) of $2000 \mu \mathrm{mol}$ (photons) $\mathrm{m}-2 \mathrm{~s}-1$ followed by dark treatment. Letters in panel (a) and (b): a. Battery; b. Wires; c. Voltage adaptor; d. Switch; e. Mixing fan (inside the chamber body); f. Digital displayed voltmeter; g. Cooling fan; h. LED array; i. Chamber body; j. Hasp; k. Sealing strip; I. Rice panicle; m. Cooling fin; $n$. Clamp. The horizontal lines in panel (g) represent mean values of the last 10 data points. The $y$-axis in panel $(\mathrm{g})$ is log-scaled.

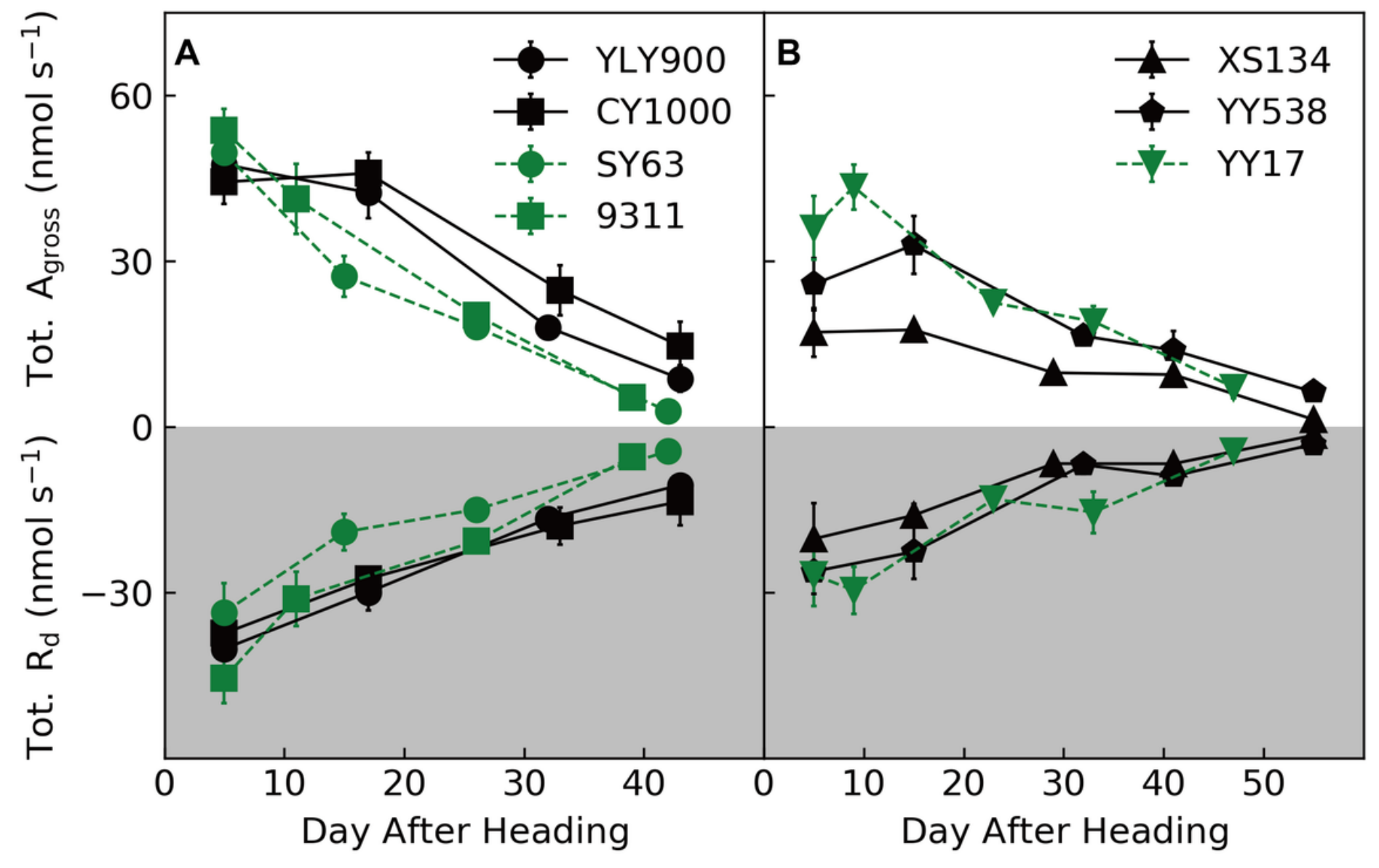

Figure 2.

Figure 2

Comparison of the gas exchange rates between indica and japonica rice cultivars 5 days after heading. a, Gross photosynthetic, net photosynthetic and respiratory rates of a whole rice panicle. b, Average gross photosynthetic, net photosynthetic and respiratory rates of a spikelet. Data of indica group were combined from rice cultivars YLY900, CY1000, SY63 and 9311; Data of japonica group were combined from rice cultivars XS134, YY538 and YY17. Data were combined from 2015 and 2016 experiments. Statistically different $p$-values were calculated from Student's t-test. 

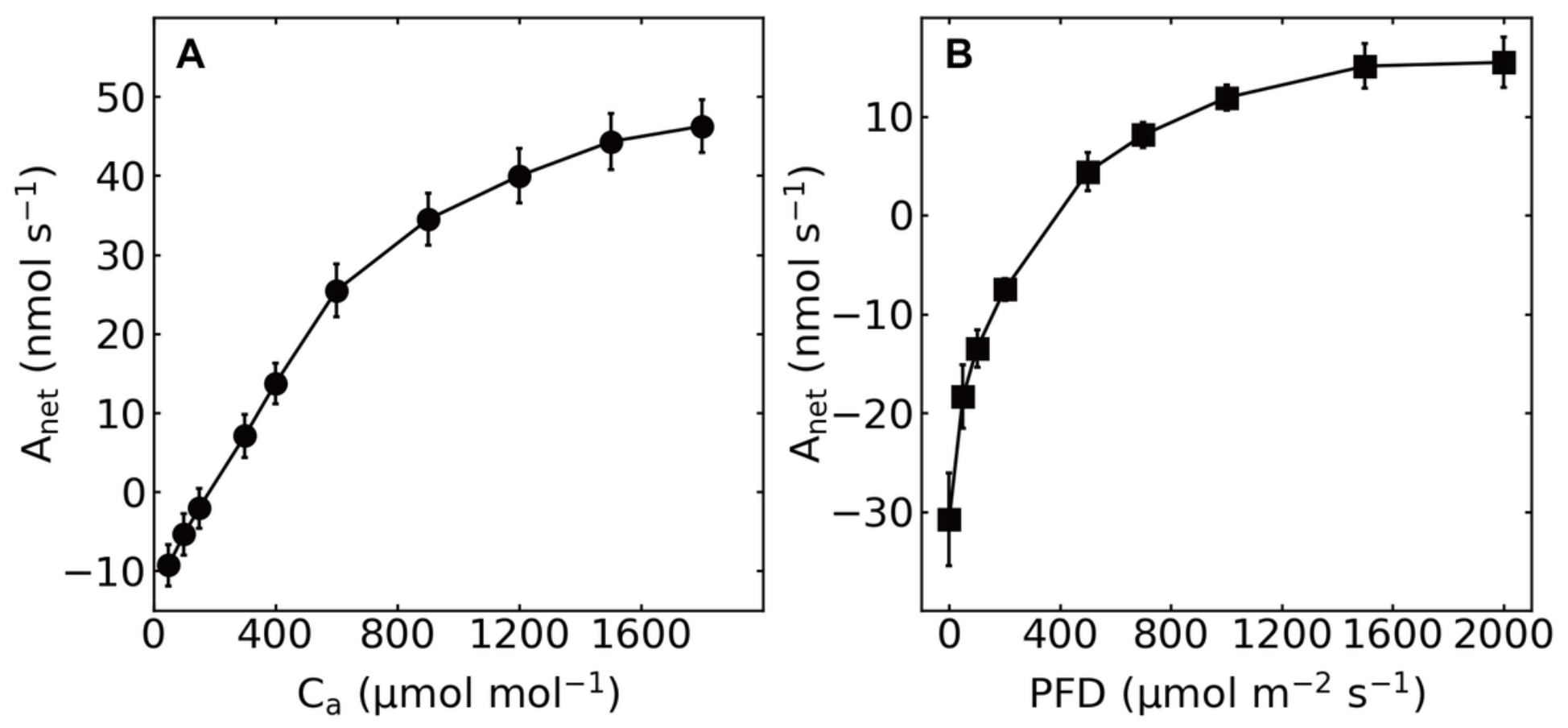

Figure 3.

Figure 3

Correlations between panicle photosynthetic gas exchange parameters normalized on a panicle basis, on a spikelet basis and on an area basis. a-c, Correlations between Agross of panicles normalized on different bases. $\mathrm{d}$-f, Correlations between Anet of panicles normalized on different bases. $\mathrm{g}$-i, Correlations between Rd of panicles normalized on different bases. Data measured in $2016(n=35)$. 


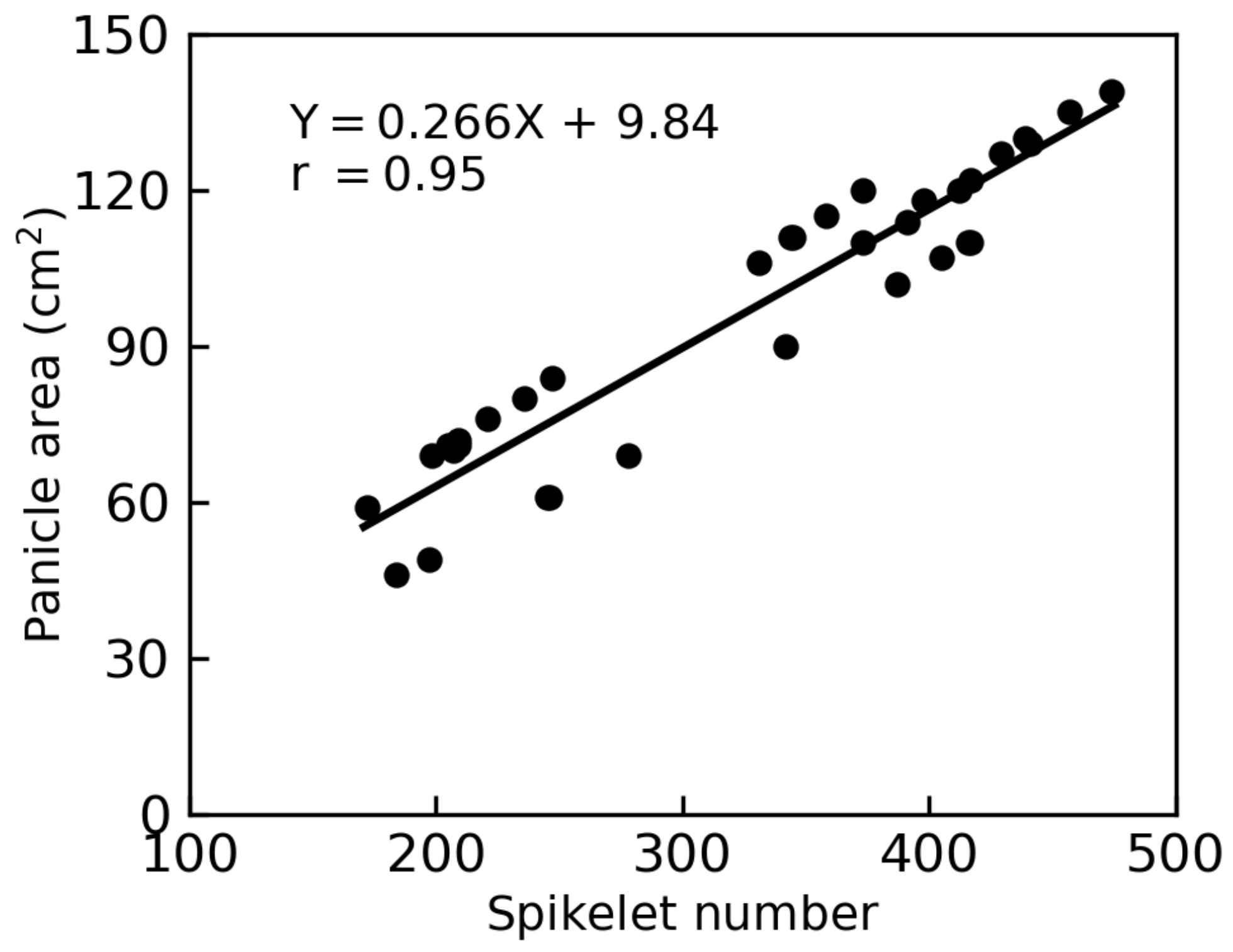

Figure 4

Correlation between panicle area and spikelet number. Data measured in $2016(n=35)$.

\section{Supplementary Files}

This is a list of supplementary files associated with this preprint. Click to download.

- supplementalinformation.docx 